UDC 372.461:37.012

DOI: 10.12958/EPS.1(162).Kazantseva_L_I

Kazantseva L. I.

\title{
LINGUODIDACTIC FOUNDATIONS OF TEACHING UKRAINIAN AS A STATE LANGUAGE TO PRESCHOOL CHILDREN IN THE CONTEXT OF MODERN SCIENTIFIC PARADIGMS
}

The methodological basis of teaching Ukrainian as a state language to preschoolers in a multicultural region encompasses a range of new scientific paradigms, including the philosophy of anthropocentrism, which sees children and their subculture as the top value; the personality-oriented educational paradigm, which emphasizes the individuality of each child and the creation of favorable conditions for the development of his/her abilities and talents; culturological paradigm, which gives attention to the child's objective and subjective connections with the culture; communicative paradigm, which implies organizing the educational process as a conversation; and competence paradigm, which involves the formation of the preschoolers' abilities and readiness to successful interaction in social, multicultural, communicative, productive, and cognitive spheres.

The early $21^{\text {st }}$ Century demonstrates the increased interest to the linguistic personality and the individual capable of communicating with the others. The ideas of anthropocentrism are related to the theory of the educational space formation in the multicultural, transformational, and innovative sense. In this kind of educational space, an individual is provided with the opportunity to freely realize his/her creative potential and capabilities, and learn about the cultural legacy of the human race. The educational process, if it is organized in the context of the childcentered approach, allows the child to participate actively in the process of his/her individual growth. Consequently, the roles of the teacher and the child start changing: viewed before as the source of information and its transmitter, the teacher turns into the organizer of the cooperative creative activity, while the child, 
who used to execute the commands of the teacher and be the "intellectual consumer", is transformed into a competent subject in the process of his/her own learning, in which the volume and significance of the individual work significantly increase. The form and styles of the relations between the participants of the educational interaction undergo some changes as well, namely the teacher's monologues in presenting the material are substituted with the dialogue between the teacher and the student, while the authoritarian tone in relations gives way to a more cooperative and personal one.

The communicative educational paradigm should be described from several perspectives. Firstly, in the context of the multicultural and multilingual nature of education, the idea of the harmonious dialogue in the community has become topical. The ability to converse, in the wide sense of the word, is seen as a sign of the cultural level of an individual or community, whereas the ability to communicate constructively is referred to as one of the key competences of a human being nowadays. Modern education, and language education as well, is characterized by the shift from monologue to dialogue teaching. Language acquisition occurs in the process of organized learning, which, in terms of content, form and the internal mechanics, should reconstruct the real-life communication in which the most crucial needs of the speaker are satisfied. Teaching a language, therefore, should be aimed at mastering the process of communication in the range of its functions, including the cognitive, value-oriented, regulative, and etiquette ones. Consequently, the dominant feature of the content of the educational process should be its communicative nature. The process of teaching a language is also directed towards cultivating standard practices and knowledge associated with language (German Sprachkultur), towards the mechanism of practical language acquisition, as well as the ability to perform the speech activity, namely speaking and listening comprehension. Therefore, mastering a language as a means of communication in its various forms is seen as the final goal in teaching a language, as well as the main way of linguistic skills development, which allows the child to internalize the expressive and content means of a language. Strategically, the 
process of language acquisition can be described as learning how to use it as a tool for communication and cognition, thinking and self-expression.

The process of teaching Ukrainian to preschoolers should be based on the competence approach. In recent decades, linguodidactics has rejected purely linguistic views of the goals, tasks, and the content of language teaching. Along with the linguistic aspect, the activity-based, culturological, communicative, and ethno-linguistic aspects have become important, since they all are oriented at the formation of the ability to deal with a range of communicative tasks. The competences acquired by children in the process of language learning, including linguistic (phonetic, lexical, grammatical, dialogue, and monologue), activity (pragmatic and strategic), and sociocultural, help to achieve the key competence, which is a communicative competence. The leading function of the language education implies the development of the linguistic personality, who has acquired the communicative culture, is capable of effective communication in all spheres of everyday life, and can determine the appropriate speech strategy and corresponding speech tactics.

The culturological educational paradigm directs language teaching methodology towards teaching a language within corresponding sociocultural context, i.e., with the culture and spirituality a particular language verbalizes. Preschoolers, being educated in a multicultural environment and exposed to several languages and cultures, will be able to acquire the Ukrainian language as the language of the state, understand it in depth, use it as an effective means of communication, and, finally, love it, provided they know and understand the culture, traditions, folklore, and native arts of the Ukrainian people. The introduction of the ethno-cultural component in the process of language teaching broadens the communicative skills of speakers and develops the motivation for learning a language. Teaching the Ukrainian language in close relation with the culturological component will help children to become aware of the special status of their native language and culture, develop eagerness to learn the language, culture, and the history of their own country. It will promote their desire to demonstrate the respect for the Ukrainian people by learning the Ukrainian 
language and communicating in Ukrainian. Taking the above-mentioned into consideration, we believe that the culturological component should be given more attention in the process of teaching Ukrainian to preschoolers, which is necessitated by the importance of the integration of the communicative and culturological aspects of language learning from the methodological point of view.

Text-oriented paradigm of language education has developed under the influence of those linguistic theories that see the text as the central unit of a language system, which relates to the reality via the text. Furthermore, all linguistic units and other language phenomena display their functions in the text, and the functioning of the system of language occurs in the text. It is also relevant because the ultimate goal in the process of language learning is the formation of the ability to produce various texts for communication. Therefore, text-oriented linguistic paradigm has resulted in the development of one of the fundamental approaches in linguodidactics - teaching language on the basis of the text. Human beings learn to understand speech through the perception of complete utterances, the text in the discourse, rather than separate words. The ability to speak is a complex set of skills aimed at the production of the text. Consequently, it is the text in the colloquial and artistic discourse should become the ground for the formation of the communicative speech activity of preschoolers; individual sentences or words are not appropriate for this purpose. In the educational process, the text should be the content component, which determines the speech topic, the vocabulary, and the situational character of the communicative speech tasks.

The implementation of the concepts mentioned above shapes the strategy of the process of teaching Ukrainian as a state (second) language to preschoolers and affects the main educational goal, namely the formation of the linguistic personality of the preschooler exhibiting communicative competence. The latter implies the ability to interact in Ukrainian in a variety of situations, desire to cooperate with Ukrainian-speaking interlocutors, and willingness to learn the Ukrainian language and literature.

The methodology of teaching Ukrainian as a state language to preschoolers is grounded on a range of fundamental principles. The principle being a more or 
less universally applicable law can be defined as a basic normative category that reflects the regularities of the educational process, directs it, determines its logics, and includes the requirements to content organization, the forms and methods of teaching. The principle implies obligation and complexity and occupies the central part in the educational process (M. Danylov, Yu. Passov, I. Pidlasyi, M. Skatkin).

Teaching Ukrainian as a second language to preschoolers is based on several groups of principles, which are hierarchically structured. In this hierarchy, principles of several ranks can be distinguished. Methodology, as any other pedagogical science, takes into consideration general didactic principles. These principles correspond to the regularities of the educational process in general and determine the activity of the teacher and the child (Yu. Babanskyi, M. Danylov, V. Sahviazynskyi, V. Kraievskyi, I. Lerner, V. Onyshchuk, I. Pidkasystyi, M. Skatkin, O. Savchenko). General didactic principles include the principle of the well-rounded development of the individual; the principle of the orientation of learning towards the solution of the educational and developmental tasks in their unity; the principle of theory and practice integration; the principle of active learning and independence; the principle of the scientific character of the educational process; the principle of accessibility; the principle of the systemic nature of the educational process; the principle of the organization of the educational process in regard to the laws related to it; the consistency and prospective orientation principles; the motivation, individualization, differentiation, and cooperation principles; the use of visual aids principles; the principle of consciousness; and the principles of sustainability and tangibility of learning outcomes.

The second rank of principles is represented by a set of general methodological principles, which are grounded on the regularities of child's speech development and reflect the dependence of the results of speech development on the formative potential of the linguistic environment. This group of principles encompasses: the principles of the correlation between language development and cognitive development and between the acquisition of the grammatical structure and the vocabulary of the language; the principles of the attention to the fabric of 
the language, of understanding language meanings, of learning a language in its structural unity; of the development of a feeling for the language; of studying language phenomena in the unity of their form and meaning; of the oral speech preceding writing; and of the dependence of language richness on the development of speech skills structure (O. Dudnikov, V. Masalskyi, L. Fedorenko, M. Shanskyi, et al.).

Teaching preschoolers a second language belongs to a specific sphere of linguodidactics, which requires that the education process be built on the basis of special principles regulating the subjects' activity in the conditions of simultaneous mastering of several languages. Thus, the principles of the third rank are specific methodological principles, which organize the process of teaching a non-native language and set its goals (B. Beliaiev, I. Bim, Ye. Verohradska, H. Horodilova, P. Hurvych, M. Illina, I. Illiasov, V. Kostomarov, V. Kraievskyi, T. Riabova, V. Skalkin, M. Khasanov, O. Shchukin, V. Tseitlin. H. Yabbarov). Specific methodological principles are: using the native language for support; communicative orientation of the educational process; the interrelation between language and speech; the connection of the linguistic and extra-linguistic factors; the relation and mutual influence of different types of speech; the mastering of linguistic knowledge by means of various kinds of speech activities; the interrelation of the levels of language; integrity; functionality; teaching on the basis of typical models; ensuring the highest level of the child's speech activity; and creating the speech environment and orientation towards learning a language.

The methodology of teaching linguistic skills is also governed by the principles of the fourth rank. These principles determine the tactics of the development of different types of speech activity and the assimilation of learning material from various spheres of linguistics. These special principles of teaching are determined by the regularities of the development of various kinds of speech activity. Every kind of speech activity requires its own system of principles, which should reflect all aspects of its teaching. V. Kraievskyi appropriately states that it is impossible to create a system of principles suitable for any and all purposes and conditions. In the end, these attempts of designing such universal system of 
principles of teaching foreign languages that disregards the goals, conditions, and regularities of learning fail [3, p. 18]. Therefore, linguodidactics traditionally distinguishes the principles of teaching speaking and listening, the principles of the formation of phonetic, lexical, grammatical, dialogue and monologue skills.

The hierarchy, or the system of principles, constitutes a graded scale of rules that function as laws with various degrees of generalization and subordination. Although these layers of principles are interconnected, interdependent, and complement each other, every principle is functionally specialized and regulates a corresponding part of the educational process.

The central category of the educational process is the method. It provides for the fulfillment of all functions of teaching: educational, developmental, motivational, monitoring, and correctional. The method of teaching is a form of the movement of the cognitive activity; it is the logical way of mastering knowledge, skills, and abilities; the kind and level of cognitive activity of the students (reproductive, heuristic, and research methods); the form of information exchange between the subjects of the educational process (verbal, visual, practical methods). "The teaching method is a form of the organized and cooperative activity of the teacher and the students aimed at the solution of the tasks of education and development in the process of teaching" [1, p. 177].

It should be mentioned that the category of method is a component of a system of education and, at the same time, the system itself, which consists of a set of elements appropriately coordinated. Basic elements of the system of the method are the techniques, which serve as means of achieving the constituent parts of the general goal. Techniques within the method are not "the sum of the components constituting the whole" (A. Aleksiuk), but a system united by logics. The specificity of every method is created by its dominant techniques.

The methods of teaching the Ukrainian language to preschoolers, or, rather, teaching linguistic skills to preschoolers, have their own characteristic features, which are related to the use of the techniques of the organization of teaching in regard to the need for considering the influence of the mother tongue on the formation of the productive skills in a second language, preventing from the 
interference of the mother tongue skills and stimulating the transfer of knowledge and skills common to the two languages. A. Bohush distinguishes four groups of techniques in the development of Ukrainian language linguistic skills, namely verbal, game, practical, and intellectual ones. Among these four groups, intellectual techniques, which stimulate the cognitive activity of children and include contrast, comparison, analysis, synthesis, generalization, differentiation, and classification, deserve special attention [2, p. 101- 104].

In the methodology of teaching a second language, techniques of teaching play a unique role, since their realization implies taking a set of actions gradually forming productive skills and abilities. Understanding the method as a way of interdependent and interrelated actions of the teacher and students, we differentiate between the techniques of teaching and the techniques of learning. The combination of techniques constitutes the method, while the exclusion or substitution of one of them alters it. The general orientation of the method is determined by the teacher's techniques and corresponding students' techniques, which speaks to the fact that the method is bilateral by nature.

The compiling of the complete register of teaching and learning techniques important for mastering the linguistic skills in a second language demonstrate that techniques of different groups are not of equal importance in the educational process. Among the techniques of coordinating children's linguistic activity, of special significance are verbal techniques used to give children an insight into the nature of linguistic means and direct conscious speech actions towards the acquisition of language means (using modeling, explanation, definitions). The dominant place in the range of student's techniques is taken up by the practical and game techniques. This corresponds to the communicative and active teaching, as well as the pragmatic teaching approach. Therefore, the use of verbal techniques in the process of coordinating the cognitive and speech activity of the child in the system of the language and the concentration on practical techniques in the process of learning a language by the preschooler encourage a step-by-step formation of the communicative linguistic skills. 
Teaching Ukrainian as a second language to preschoolers should be seen as the process of communicative speech formation, which encompasses a range of linguistic skills in using language means of different levels and the ability to synthesize them to create a speech product for the solution of practical tasks. It should also be borne in mind that verbal communication is always a creative process, and the achievement of the main (communicative) goal can never be easy. The formation of every skill at various language levels and pertaining to a specific kind of speech activity happens in the course of their qualitative transformation from one state into a principally different new state, namely from becoming aware of the language phenomenon, understanding the peculiarities of its functioning in a language, its imitation and reproduction into the ability to use it with the help of supporting algorithms, models, samples, and further into the independent use of the language unit in speech production. This process illustrates the formation of automated skills, which function in the speech. To become automated, skills should be repeatedly used in speech, gradually becoming more and more complex and incorporating other skill and abilities that were developed previously. In this way, teaching may be represented as a concentric spiral, in which every round includes specific stages of teaching, but at a new, higher and quantitatively prevailing, level.

We distinguish four stages in teaching Ukrainian as a state (second) language to preschoolers, namely cognitive orientation stage, which in accord with the main direction of learning corresponds to the development of the receptive speech; practical application stage related to the development of the reproductive speech of the preschoolers; practical reproduction stage which implies the development of the productive speech; and the communicative and creative stage, which means that the child is autonomously bilingual and is able to successfully use the Ukrainian language in a variety of communicative situations.

The aim of the first cognitive orientation stage is to enrich the children's knowledge of the world, introduce them to the Ukrainian culture, and form an ability to present their knowledge of the world, culture, and people by means of the Ukrainian language at a basic level. This stage also implies teaching children to 
understand everyday conversations and simple literary texts in Ukrainian and repeat individual words and phrases.

Even at the very first stage, the process of teaching Ukrainian should be integral, therefore semantization and the introduction of new items of the active vocabulary, the explanation of phonetic and grammatical peculiarities of the Ukrainian language on the basis of comparison and contrast are compulsory.

The aim of the second stage of practical application can be described as teaching children to reproduce the information from various sources in simple utterances. At this stage, it is important to encourage children to learn about the Ukrainian literature, culture, and arts; improve their listening skills and ability to consciously perceive coherent literary text and everyday speech; allow them to imitate language units of various levels (sounds, sound sequences, words, word forms, word groups, sentences, and phrases) understanding their linguistic peculiarities and being aware that they belong to the Ukrainian language on the basis of comparison with other languages. This is also the time to form primary abilities of preschoolers to creatively use the acquired lexical material in a variety of speech products by analogy with the grammatical, syntactic, and dialogue models.

The third stage of practical reproduction should be directed towards the automatization of phonetic, lexical, morphological, and syntactic skills in independently produced utterances in pseudo-communicative activities. Teacher's efforts should be focused on the development of the child's skills in the selection from a variety of the acquired language means the linguistic units that suit the communicative goals of the situation. At this stage, children are taught to combine the orthoepic, lexical, and grammatical skills in a coherent speech. Attention should also be paid to the development of language and inter-language feeling and stimulation of self-correction.

The fourth communicative and creative stage embraces the final consolidation of the Ukrainian language communicative linguistic skills of preschoolers. Children should be taught to produce utterances of various types and genres for the effective realization of the goal of communication; independently, 
appropriately, and creatively select linguistic units that correspond to the communicative situation. The teacher should also continue to develop the child's listening and speaking skills by introducing him/her to such tasks as retelling the information he/she has read or heard, reproducing the content of the literary work in drama and role plays, expressing his/her attitude and feelings, evaluating the events and characters, etc. At this stage, the teacher's efforts should also be directed toward the improvement of interactional and transactional skills: the child must be taught to initiate and maintain conversations, observe the rules of the communicative culture, use a wide range of verbal and non-verbal means of communication; compose discourse of various types, including stories and narratives, on the basis of his/her own or collective experience, as well as imaginary ones.

Every stage described above has a dominant group of methods. For instance, for the cognitive orientation stage the methods of observation, excursion, object examination, watching films and TV programs, story telling (performed by the teacher), reading literary works, role-plays are important. The use of these methods provides for the material that becomes the basis for mastering language means and forming linguistic skills. The most important teaching techniques at this stage encompass teacher's story telling, the demonstration of objects and their qualities and features, the demonstration of actions and movements with the simultaneous naming, the description of the objects and phenomena, the definition of the notions, the clarification of the meanings of the words, reading or citing the literary works, questioning, etc.

Except for the enrichment of the child's cognitive sphere, his/her introduction to the specificity of the system of the Ukrainian language occurs at this stage. With the help of special techniques, Ukrainian language phenomena are presented, the characteristic features of the pronunciation of the sounds and sound sequences are explained, stress differences in similar words of the two languages are emphasized, and the peculiarities of the grammatical forms and derivation are singled out. The translation and contrast used in the process of vocabulary work and in the presentation of the phonetic and grammatical phenomena of the 
Ukrainian language are of special importance at this stage. The direct translation technique, namely the translation from the child's mother tongue into Ukrainian, is an appropriate tool in the process of child's cognitive orientation, since it prevents from the interferential errors, which is critical in the case of the linguistic similarity of language systems.

The relatedness of the Ukrainian and Russian languages, the similarity of their structure almost at all language levels, and, at the same time, the differences that these two languages exhibit bring about the need for the constant work on the similar and the distinctive in the educational process through contrasting the linguistic material of the two languages. When introducing new material, the technique of an open inter-language contrast is used in all cases when the linguistic phenomena have significant or partial differences. The contrast of linguistic facts should run from the information children know, namely from their native language; having singled out the differences, the teacher should focus the children's attention on the difference in the Ukrainian language.

Practical application stage is characterized by the increasing role of independent practical activity with language units in imitations, analytical and filling-in tasks, games (didactic, round dance, active games with language components), learning short pieces of folklore, poems, and songs by heart. Generally, this stage is aimed at the conscious reproduction of the language units of the Ukrainian language and development of primary language skills. In tasks and games, children repeat linguistic units and learn to use them consciously in accord with the model provided. Children also try to reproduce simple coherent texts that were presented at the previous stage. To avoid mechanic reproduction, the teacher has to make sure that children understand the literary work or story by means of asking alternative or general questions, which require one-word answers.

The work at the vocabulary is also an important part of this stage. We believe that vocabulary work will be more effective if it is carried out on the basis of coherent texts. The linguistic analysis of texts demonstrates that they can provide for the enrichment of the child's speech with figurative lexical units. Moreover, the use of texts in language teaching creates the conditions necessary 
for a wide range of learning situations in which lexical units along with the grammatical forms are mastered. For the semantization of the lexical units, the teacher should use translation techniques, explanations of the unknown words, and notion descriptions, after which preschoolers learn to use new words in speech. It should be emphasized that new words should be immediately incorporated in communicative speech, but not mechanically reproduced in isolation. To promote communicative speech, the teacher can create situations or ask question, giving the answer to which will require the use of the necessary lexeme. This stage is also characterized by the accumulation of language units, thus requiring the application of the method of short stories retelling, learning poems by heart, making up dialogues and monologues using samples.

The stage of practical reproduction includes construction and transformation activities, which consolidate primary skills and change them into the partially communicative skills. Doing these exercises requires much effort, more complex mental operations, and preparedness for transfer, which is the use of basic linguistic skills in new communicative situations. The construction and transformational activities represent the transition period between the reproduction and communication. Preschoolers start using the units of a higher level of the language hierarchy, such as word groups, sentences, and phrases consisting of structurally diverse sentences, which are the smallest units of communication. The construction and transformation activities encourage children to build or change the structure of sentences, word groups or dialogue parts following the instruction. In this way, they consolidate their skills in creating grammatical forms, using the words in agreement and their correct pronunciation, creating the sentences of the required structure. Communicative speech tasks serve to achieve phonetic, lexical, and grammatical objectives. Binary techniques applied at this stage include the teaching technique of creating a game situation and the learning technique of assuming a role and choosing adequate linguistic behavior tactics; the instructions on how to do the tasks on the part of the teacher are combined with the realization of the speech actions in tasks (games) on behalf of the student; teacher's comments about mistakes are followed up by the correction of the mistake by the child. 
The construction and transformation activities focused on the formation of lexical, derivational, and grammatical skills are a firm ground for the development of a coherent speech. The methods of interactional skills formation include the discussion of the content of a literary work or the teacher's story telling; making up dialogues independently on the basis of real-life or imaginary situations from the text; didactic games including dialogues; dramatization or role play; drama games. The method of transactional skills development used at this stage embraces retelling, object or toy description, telling a story using pictures, game situation or one's own experience. The techniques for transactional skills development include the model story introduction, the analysis of the structure and content of the model story; the story plan suggested by the teacher; the story plan made up cooperatively; composing a story using picture or schemes.

The methods of the final - communicative and creative - stage are concentrated on the formation of the communicative skills of the independent composition of utterances of various types and genres in a range of communicative situations; the development of the child's ability to creatively select communicatively adequate linguistic units. The methods of teaching are games and real communicative situations; conversations, discussions of the content of the texts or of the moral or ethic problems; didactic games; drama games; role plays; composition of various types of stories.

Taking the above-mentioned into consideration, it should be emphasized that the modern approach to teaching Ukrainian to preschoolers should be based on the principles of neo-humanistic philosophy, communicative, competence, culturological and text-oriented approaches. These scientific paradigms determine the goals, content, tools, and techniques used in the process of teaching Ukrainian to children.

The formation of every speech skill and communicative speech in general goes through a set of stages, from basic assumptions about the surrounding world and the means of manifestation of this knowledge with the help of the Ukrainian language units to the ability to independently use these means in one's communicative activity. The process of the formation of communicative skills in 
the Ukrainian language occurs in four sequential stages, namely cognitive orientation stage, practice application stage, practical reproduction stage, and communicative and creative stage.

\section{References}

1. Babanskyi Yu. K. Metody obucheniia v sovremennoi obshcheobrazovatelnoi shkole: uchiebnoe posobie [Methods of Teaching in Modern Secondary School: a textbook]. Moscow: Prosveshcheniie. 1985. 206 p. (rus)

2. Bohush A. M. Metodyka navchannia ditei ukrainskoii movy v doshkilnykh zakladakh: pidruchnyk [Methodology of Teaching Ukrainian to Children in Kindergartens: Textbook]. Kyiv: Vydavnytstvo Slovo. 2008. 440 p. (ukr)

3. Kraievskyi V. V. Metodologiia pedagogiki: posobiie dlia pedagogovissledovatelei [Methods in Pedagogy: Manual for Research Educators]. Cheboksary: Zidatelstvo Chuvashskogo Universiteta. 2001. 244 p. (rus)

Казанцева Л. І.Лінгводидактичні засади навчання дошкільників української мови як державної у світлі сучасних наукових парадигм

Стаття висвітлює теоретично-методичні проблеми навчання дітей української мови в національних дошкільних установах на основі особистісно зорієнтованої, культурологічної, компетентнісної та комунікативної парадигм. Процес упровадження освіти за вказаною основою трансформує стратегію викладання української мови, створює основу для реконструкції україномовної освіти в дошкільних установах національних громад. Лінгводидактична основа методики викладання нерідної мови дітям дошкільного віку визначає ієрархію певних принципів (загальнодидактичних, частководидактичних, спеціальних), які залежать від головної мети мовної освіти та впливають на організацію навчального процесу, визначають завдання та інструментально-технологічний аспект процесу розвитку мовлення. 
Викладання української мови відповідно до моделі, яку подано в статті, становить процес, який будує комунікативну активність, що поділяється на чотири етапи (пізнавально-орієнтувальний, практично-виконавський, практично-продуктивний, комунікативно-творчий). Ці етапи відповідають за певні ступені мовленнєвої активності дошкільників. Кожен етап має свою мету й вирішує актуальні завдання мовленнєвого розвитку завдяки системі домінантних методів, засобів і типу навчання. Уся лінгвометодична модель викладання української мови як другої спрямована на формування автономної, продуктивної двомовної діяльності дошкільників.

Ключові слова: лінгводидактика, дошкільна освіта, державна мова, система принципів навчання, прийоми навчання.

\section{Казанцева Л. И. Лингводидактические основы обучения} дошкольников украинскому языку как государственному в свете современных научных парадигм

Статья освещает теоретико-методические проблемы обучения украинскому языку в национальных дошкольных учреждениях на основе личностно ориентированной, культурологической, компетентностной и коммуникативной парадигм. Процесс внедрения образования по указанным выше направлениям трансформирует стратегию преподавания украинского языка, создает основу для реконструкции украиноязычного образования в дошкольных учреждениях национальных общин. Лингводидактическая основа методики преподавания неродного языка детям дошкольного возраста определяет иерархию определенных принципов (общедидактических, частнодидактических, специальных), которые зависят от главной цели языкового образования и влияют на организацию учебного процесса, определяют задачи и инструментально-технологический аспект процесса развития речи.

Преподавание украинского языка в соответствии с моделью, представленной в статье, представляет собой процесс, который формирует коммуникативную активность, делится на четыре этапа (познавательно 
ориентированный, практико-исполнительский, практико-продуктивный, коммуникативно-творческий этапы). Эти этапы отвечают за определенные степени речевой активности дошкольников. Каждый этап имеет свою собственную цель и решает актуальные задачи речевого развития, благодаря системе доминирующих методов, средств и типа обучения. Вся лингвометодическая модель преподавания украинского языка как иностранного направлена на формирование автономной, продуктивной двуязычной деятельности дошкольников.

Ключевые слова: лингводидактика, дошкольное образование, государственный язык, система принципов обучения, приемы обучения.

Kazantseva L. I. Linguodidactic Foundations of Teaching Ukrainian as a State Language to Preschool Children in the Context of Modern Scientific Paradigms

The article discusses the theoretical and methodological problems of teaching the Ukrainian language to children in the national preschool establishments in the light of personality-oriented, culturological, competence, and communicative paradigms. The process of implementing education on the ground of these approaches lead to the transformation of the strategy of teaching the Ukrainian language and creates the necessary foundation for upgrading Ukrainian language education in the preschool establishments. The linguodidactic basis for the methodology of teaching a non-native language to preschoolers determines the hierarchy of principles (including general didactic, specific didactic and filed specific), which depend on the goal of language education and affect the educational process organization, influence the tasks and choice of the instruments and technique of speech development.

Teaching the Ukrainian language according to the model described in the article can be defined as the process of forming the communicative activity of a child. This process encompasses four stages, namely the stage of cognitive orientation, the stage of practical application, the stage of practical reproduction, and the communicative and creative stage. These stages correspond to various 
degrees of preschoolers' speech activity, have their own goals and tasks related to speech development, and are based on the system of dominant methods, means and types of teaching. The linguomethodological model of teaching Ukrainian as a foreign language is aimed at the formation of autonomous, productive bilingual activity of the preschoolers.

Key words: linguodidactics, preschool education, state language, system of educational principles, educational means.

The article was received by the Editorial Office on 11.09.2013 The article was put into print on 28.02.2014 Peer review: Halych O. A., Doctor of Pedagogical Sciences, Professor 